stance is only present in small quantities, as in fresh-water lakes, the vegetable matter is left simply as lignite.

If we study the details recorded from borings in the deposits forming any great delta, we cannot fail to be struck with the correspondence between these details and those of the case we have been considering. The beds of "peat" so commonly met with generally represent, I consider, the deeper-water accumulation of vegetable matter I have so often referred to. Some, of course, may be true soils; but the majority are far more likely to be due to the causes above noticed. If this view be accepted as true in the main, then it is obvious that we must cease to regard these beds of "peat" as evidence of the former presence of dry land at a platform that owes its present position to submergence at a later date. They should be regarded as simply an integral part of the normal sedimentary deposits that had been formed there; the peat representing, not shallow water nor subaërial conditions, but simply deposits that had been laid down in the ordinary course in water that was comparatively deep.

We have but to imagine such beds of the submarine "peat" exposed to the necessary conditions of pressure and chemical change, and beds of coal would be formed identical in nearly all respects with such as had grown, had died, and had been entombed on the spot.

\title{
V.-Note on some Pebbles in the Basal Conglomerate of the Cambrian at St. Davids.
}

By Prof. T. G. Bonney, D.Sc., LL.D., F.R.S., F.G.S.

$M^{\circ}$ ORE than one kind of rock, as we learn from Dr. H. Hicks and other writers, ${ }^{1}$ occurs in the conglomerate which forms a wellmarked base to the Cambrian system at St. Davids. Sometimes the pebbles are mainly vein quartz, sometimes felstone predominates, but occasionally, as in the neighbourhood of Nun's Chapel Bay, quartzites (using the term rather generally) are not uncommon. At one place, not far from a quartz-felsite dyke, these are rather large, occasionally about a foot in diameter. From this locality, while spending a few days at St. Davids in 1882, I brought away specimens of three of the most marked varieties of quartzite, of which I had slices prepared, thinking that as examples of rocks which were probably far from modern at the beginning of the Cambrian age, their structures might be instructive. In this I was not disappointed, and now that I have had many opportunities of comparing them with various quartzose rocks, both Palæozoic and Archæan, I think a brief description may have some general interest.

The first, and least remarkable, was broken from a rather angular block about a foot in its longest diameter. The rock is a quartzite, rather compact or even vitreous in aspect, nearly white, or of a very pale pinkish-grey colour. Microscopic examination shows it to be composed almost entirely of quartz. This occurs in grains, from

1 Q.J.G.S. vol, xl. p. 567 , id. (Blake) p. 294. 
subangular to rather rounded in form, which are often about $\cdot 015^{\prime \prime}$ to $\cdot 02^{\prime \prime}$ in diameter. It is difficult to be quite certain of the boundaries of the original fragments, but secondary quartz more or less in optical continuity with the original grain has undoubtedly been deposited to some extent. Here and there a tiny flake of light-coloured mica, or a little opacite or ferrite, may be seen, indicating no doubt the residne of the dusty material once present in the original sandstone. One or two of the fragments exhibit a compound structure. Very minute fluid cavities with bubbles are rather numerous in the quartz grains; but on these, and a few tiny accidental microliths, it seems needless to dwell.

The next specimen comes from a block of nearly the same size. It is a fine-grained quartzite, slightly rougher in texture and fracture than the last, and of a purple-grey colour. Examination with a lens shows that, though composed mainly of quartz, a good many tiny flakes of silvery mica are present. Microscopic examination shows that the quartz grains, though rather smaller in size, are very commonly about $012^{\prime \prime}$ diameter, and somewhat rounded or bluntly polygonal, but slightly wavy in outline. Occasionally they are separated by a flake of mica: more often a few specks of opacite or ferrite indicate the position of the original contact surface. Doubtless the original grains have been augmented by deposit of secondary quartz; but, even more than in the former case, it is difficult to fix the position of the old surface. Still I should infer that the grains had once been fairly regular in outline. Fluid cavities appear to be less numerous than in the former case. The mica is white or a very pale greenish tint; it occurs sometimes in isolated flakes, but is frequently associated and occasionally almost forms "nests," when it is usually mixed up, more or less, with dark granules, which are probably, in part at least, hematite and magnetite. The larger flakes are about $\cdot 01^{\prime \prime}$ in length, but the majority are smaller. The sections are fairly rectilinear in outline: the shorter ends not appearing either ragged or " nipped." Even if originally fragmental, these flakes must have been subsequently enlarged, and I suspect that they have been to a great extent, if not wholly, developed in situ. Possibly some tiny crystals of zircon and rutile are present, with perhaps a grain of epidote: but these accessories are so unimportant, that I have not cared to waste time in attempting to determine them with precision.

The next fragment is from a fairly rounded stone about four inches long. This quartzite is whitish in colour, and in structure is fine-grained and rather schistose. Microscopic examination shows that quartz is the principal mineral. The grains commonly present 'ragged' outlines, and are unequal in dimensions, tending to lie with their longer axes parallel. When viewed with crossing Nicols each grain exhibits a border tinted rather differently from the inner parts. This might be produced by the overlapping of the irregular edges of two contiguous grains; but as the tint in some cases continues practically uniform all round the grains, it must result eitber from a fairly regular thinning of the latter, or 
from a deposit of secondary quartz which is not in optical continuity with that of the original grain. The mica flakes, practically colourless, vary in length up to about $\cdot 006^{\prime \prime}$, and often lie between this and $\cdot 004^{\prime \prime}$, they tend to lie parallel one to another, and exhibit bright tints with crossed Nicols. The slide contains two or three grains of brown tourmaline, some microlites of zircon and rutile (probably), some tiny flakes of iron-glance, and some opacite or ferrite.

It seems reasonable to suppose that all these rocks were originally clastic, consisting of moderately worn fragments of quartz, which must have been derived from some more ancient and probably granitoid rock, with a variable amount (in one case extremely little) of mud, which has subsequently been converted into white mica and secondary quartz.

My collection contains a fair number of slides representing quartzites of Palæozoic or presumably Palæozoic age, from various localities in Britain ${ }^{1}$ and from a few other quarters. These, however, differ slightly from the first-named specimen, and considerably from the others: the alteration of the constituents, especially in regard to the more earthy, being less complete. But the second specimen bears in some respects a close resemblance to certain quartzites which I obtained from the Huronian Series near Sudbury in Canada. ${ }^{2}$ In these we find mica flakes, if not developed, at any rate completed in situ. True, in most of these specimens the mica is brown, but white mica may also be found, especially in one whitish quartzite which much resembles this rock from St. Davids. Again, the third fragment from that locality is different from any specimen of Palæozoic quartzite which I have ever examined, and closely resembles the schistose quartzites or quartz-schists which $I$ have found associated with the more fine-grained mica-schists and chloriteschists in the Alps and elsewhere. It almost exactly resembles one described by $\mathrm{me}^{3}$ from above Windisch-Matrei (Tyrol), except that the last-named is slightly coarser in texture and a little more definitely foliated. Both the second and third specimens from St. Davids present some resemblance to a quartzite ${ }^{4}$ which, at Pen-y-Parc, near Beanmaris (Anglesey) occurs in association with one of the greenishgrey micaceous schists, which are so abundant in that island.

The quartz grains in the more highly-altered quartzose rocks of clastic origin exhibit under the microscope (as no doubt has often been remarked) a fairly distinct peculiarity of aspect. The edges of the individual grains appear, as it were, fused together. The line of junction is often slightly wavy, irregular, almost inter-

${ }^{1}$ e.g. N.W. Scotland, Hartshill, Lickey, Wrekin, Stiper Stones, N. Wales, Cherbourg, the Ardennes, pebbles from Carboniferous and Triassic rocks, etc.

2 Described in Q.J.G.S. vol. xliv. p. 32.

3 Q.J.G.S. vol. xiv. pp. 87-105.

4 See Q.J.G.S. vol. xxxix. p. 47 (note). Prof. Blake (id. vol. xliv. 475, 50s) calls this a quartz knob, and seeks to show that it has more resemblance to a vein product than to a rock of clastic origin. I cannot, of course, answer for the specimen which he examined, but can only say that if $\mathrm{my}$ slide does not represent a quartzite, I have never seen one. 
locking, as if the mass had been reduced to a plastic condition and then slightly but rather uniformly compressed in all three dimensions of space, or as if the grains had been growing gradually outwards at the expense of a semi-fluid magma which had filled up all the interstices. A rather similar aspect is presented by quartz grains, which have formed (often mainly by segregation-though no doubt frequently around a clastic nucleus) in a 'silty' rock which has been much affected by 'contact metamorphism.' similar aspect is presented by the quartzes in certain quartzose schists, which are presumably metamorphosed sediments, and which do not appear to have been subsequently very distinctly modified by pressure. This peculiarity - though distinct to an accustomed eyeis not very easy to describe in words or even to represent diagrammatically; but an idea of it may be obtained by comparing the lower half of figure 3 (omitting some of the small interstitial granules) with figs. 1 and 2 and the upper halves of 3 and 4 of plate xxxi. in the late Prof. R. D. Irving's excellent paper on the Archæan Formation of the North-Western States. ${ }^{2}$ A hard and fast line, as indeed these figures show, cannot be drawn between this structure and that of an ordinary quartzite-still, I believe. a very large number of specimens can be classed under one or the other type; and I am quite certain that if these three specimens from St. Davids had been sent to me (as specimens often are sent) without any clue as to their geological horizon, I should have returned them with the remark that they had the appearance of being very ancient rocks.

Here, then, at the base of the British Cambrians, we find, in three specimens selected as fair samples of the materials of a conglomerate, structures, of which one indicates that the rock is not likely to be anything but ancient; the second is more like the structure of the Huronian quartzites than of any indubitable Palæozoic quartzite which I have examined; and the third resembles that of quartz-schists, which are almost certainly Arcbæan, though they probably do not belong to the oldest part of that series. The structures also of these two are not such as are suggestive of pressure metamorphism, but of slow molecular change, under constraint indeed, in the presence of water, and at a fairly high temperature. Thus the evidence of these pebbles, so far as it goes, is favourable to the opinion that, as a general rule, ${ }^{3}$ rocks of Archæan age may be identified by their structures, and that the conditions under which they consolidated have recurred, if at all, only rarely and locally.

1 See, for instance, Q.J.G.S. vol. xliv. p. 16.

2 United States Geological Survey, Fifth Annual Report, 1883-4.

${ }^{3}$ I must not be supposed to assert that a hard, fast, and universal line can be drawn between Archæan and Palæozoic (or Cambrian and Pre-Cambrian) any more than between Paliozoic and Mesozoic or between any other geological groups, systems, or classificatory divisions. 